Artikel

\title{
Kombinasi Tehnik Relaksasi Nafas Dalam dengan Terapi Akupresur dalam Menurunkan Tekanan Darah Penderita Hipertensi
}

\section{The Combination of Deep Breathing Relaxation with Acupressure Therapy in Reducing Blood Pressure of Hypertension Patients}

\author{
Murwidi, Imam Cahyo; Muhlis, Rasdiyanah
}

\author{
Imam Cahyo Murwidi \\ imam.cahyo.murwidi@gmail.com \\ Poltekkes Kemenkes Ternate, Indonesia \\ (D) Rasdiyanah Muhlis \\ Poltekkes Kemenkes Ternate, Indonesia
}

\author{
Health Information: Jurnal Penelitian \\ Poltekkes Kemenkes Kendari, Indonesia \\ ISSN: $2085-0840$ \\ ISSN-e: 2622-5905 \\ Periodicity: Bianual \\ vol. 13, no. 1,2021 \\ jurnaldanhakcipta@poltekkes-kdi.ac.id
}

Received: 05 May 2021

Accepted: 14 June 2021

URL: http://portal.amelica.org/ameli/journal/504/5042198004/

DOI: https://doi.org/10.36990/hijp.v13i1.288

Funding

Funding source: Poltekkes Kemenkes Ternate

Contract number: HK.02.03/1/2020/2019

Corresponding author: imam.cahyo.murwidi@gmail.com

Authors retain copyright and grant the journal right of first publication with the work simultaneously licensed under a Creative Commons Attribution-ShareAlike 4.0 International License that allows others to share the work with an acknowledgment of the works authorship and initial publication in this journal and able to enter into separate, additional contractual arrangements for the non exclusive distribution of the journals published version of the work (e.g., post it to an institutional repository or publish it in a book).

This work is licensed under Creative Commons AttributionShareAlike 4.0 International.
Ringkasan: Hipertensi merupakan penyakit silent killer (pembunuh diam-diam) karena jarang memiliki gejala yang jelas dan dapat menimbulkan banyak komplikasi. Oleh karena itu, diperlukan upaya deteksi dini dan penatalaksanaan yang efektif. Penelitian ini bertujuan untuk mengetahuai pengaruh kombinasi relaksasi nafas dalam dengan terapi akupresur dalam menurunkan tekanan darah pada penderita hipertensi. Jenis peneletian ini adalah penelitian eksperimen semu dengan menggunakan rancangan penelitian one group pre \& post-test design. Sampel dalam penelitian ini adalah pasien hipertensi primer di wilayah kerja Puskesmas Siko Kota Ternate sebanyak 30 orang. Hasil penelitian ini menunjukkan terdapat perbedaan bermakna antara rerata tekanan darah sistolik pre152,33 $\pm 13,05$ $\mathrm{mmHg}$ dengan post $142,67 \pm 15,74 \mathrm{mmHg}$ (p:0,000), post 15 menit pertama $137,67 \pm 15,24 \mathrm{mmHg}$ (p:0,000), post 15 menit kedua $136,00 \pm 14,99 \mathrm{mmHg}$ (p:0,000). Terdapat perbedaan bermakna antara rerata tekanan darah diastolik pre 90,00 $\pm 8,65$ mmHg dengan post $84,33 \pm 7,28 \mathrm{mmHg}$ (p:0,000), post 15 menit pertama $83,00 \pm 7,02 \mathrm{mmHg}$ (p:0,000), post 15 menit kedua $82,67 \pm 7,40 \mathrm{mmHg}$ (p:0,001). Dapat disimpulkan bahwa kombinasi relaksasi nafas dalam dengan terapi akupresur dapat menurunkan tekanan darah penderita hipertensi.

Kata kunci: Relaksasi nafas dalam, Tekanan darah, Terapi akupresur.

Abstract: Hypertension is a silent killer disease because it rarely has clear symptoms and can cause many complications. Therefore, early detection and effective management are needed. The study purpose to determine the effect of a combination of deep breathing relaxation with acupressure therapy in reducing blood pressure of with hypertension patients. The study method is quasi-experimental using one group pre $\&$ post-test design. The sample in this study were 30 patients with primary hypertension in the working area of the Siko Health Center in Ternate. The results of this study indicate that there are significant differences between the mean systolic blood pressure of pre $152.33 \pm 13.05$ $\mathrm{mmHg}$ with post $142.67 \pm 15.74 \mathrm{mmHg}$ (p: 0.000), first post 15 minutes $137.67 \pm 15.24 \mathrm{mmHg}$ (p: 0,000 ), second post 15 
minutes $136.00 \pm 14.99 \mathrm{mmHg}$ (p: 0,000). There was a significant difference between the mean diastolic blood pressure pre 90.00 $\pm 8.65 \mathrm{mmHg}$ with post $84.33 \pm 7.28 \mathrm{mmHg}$ (p: 0,000), first post 15 minutes $83.00 \pm 7.02 \mathrm{mmHg}$ (p: 0.000 ), second post 15 minutes $82.67 \pm 7.40 \mathrm{mmHg}$ (p: 0.001). Conclusion: It can be concluded that the combination of deep breathing relaxation with acupressure therapy can reduce blood pressure in hypertension patients.

Keywords: Acupressure therapy, Blood pressure, Deep breath relaxation.

\section{PENDAHULUAN}

Perkembangan zaman dan perubahan gaya hidup menyebabkan tren penyakit tidak menular meningkat. Hipertensi merupakan salah satu penyakit tidak menular yang memiliki prevalensi tinggi. Hipertensi atau penyakit tekanan darah tinggi merupakan suatu kondisi dimana tekanan pembuluh darah mengalami peningkatan di atas ambang normal (WHO, 2013). Banyak komplikasi yang ditimbulkan oleh hipertensi apabila tidak dilakukan penatalaksanaan dengan baik, diantaranya gagal jantung, stroke, gagal ginjal, kebutaan, dan gangguan kognitif(WHO, 2013).

Hipertensi saat ini menjadi masalah kesehatan global yang menjadi perhatian serius. Menurut Word Health Organization (2013) secara global penyakit kardiovaskuler menyumbang sekitar 17 juta kematian per tahun, hampir sepertiga dari total angka kematian di dunia (WHO, 2013). Dari total tersebut, komplikasi hipertensi menyebabkan 9,4 juta kematian di seluruh dunia tiap tahunnya. Berdasarkan hasil Riset Kesehatan Dasar (Riskesdas) tahun 2018 prevalensi hipertensi di Indonesia mengalami peningkatan. Pada tahun 2013 prevalensi hipertensi 25,8 persen, sedangkan di tahun 2018 naik menjadi 34,1 persen (Kemenkes RI, 2013, 2018). Tingginya prevalensi hipertensi ditentukan oleh faktor perilaku dan metabolik. Faktor perilaku diantaranya adalah konsumsi makanan yang mengandung banyak garam dan lemak, konsumsi alkohol, merokok dan menejemen stress yang buruk. Sedangkan faktor metabolik yaitu obesitas, diabetes mellitus dan peningkatan lipid darah (Anderson et al., 2016).

Pemeriksaan tekanan darah secara berkala pada hipertensi sangat diperlukan sebagai upaya deteksi dini. Untuk menghindari terjadinya komplikasi, penatalaksanaan hipertensi harus dilakukan dengan baik dan efektif. Penatalaksanaan hipertensi dapat dilakukan secara farmakologis maupun nonfarmakologis. Upaya penatalaksanaan hipertensi secara nonfarmakologis yang dapat dilakukan adalah membatasi konsumsi garam dan makanan tinggi lemak, tidak merokok, tidak minum alkohol, manajemen stress yang baik (Anderson et al., 2016) melalui pemberian edukasi yang baik (Rahayu et al., 2018).

Stress merupakan salah satu faktor resiko dari hipertensi (Anderson et al., 2016). Menejemen stress yang baik pada penderita hipertensi diperlukan untuk mengontrol tekanan darah. Banyak cara yang bisa dilakukan untuk menejemen stress, salah satunya adalah tehnik relaksasi nafas dalam. Tehnik relaksasi nafas dalam dapat mempertahankan aktivitas saraf parasimpatis dan mengurangi 
aktivitas saraf simpatis (Komori, 2018). Ada pengaruh yang signifikan antara tekanan darah sebelum dan sesudah dilakukan teknik relaksasi nafas dalam (Wijayanti \& Setiyo, 2017).

Penatalaksanaan hipertensi secara nonfarmakologis lainnya yang bisa dilakukan adalah terapi akupresur. Akupresur merupakan terapi dengan memberikan rangsangan (stimulasi) pada titik-titik akupunktur tertentu dengan teknik penekanan atau teknik mekanik (Kemenkes RI, 2014). Penelitian yang dilakukan oleh Lin (2016) menunjukkan hasil terapi akupresur pada titik taichong dapat membantu menurunkan tekanan darah penderita hipertensi (Lin et al., 2016). Titik ini disebut juga titik LV3 yang terletak antara metatarsal pertama dan kedua (Lin et al., 2016; Saputra et al., 2020).

\section{METODE}

\section{Jenis Penelitian}

Penelitian ini merupakan kuasi eksperimen pada satu kelompok yang diberikan terapi akupresur dengan pra-pascates sebelum dan setelah terapi.

\section{Lokasi, Waktu, Populasi dan Sampel}

Penelitian dilaksanakan di Puskesmas Siko Kota Ternate pada bulan September 2019 dan populasi penelitian adalah seluruh penderita hipertensi di wilayah kerja Puskesmas Siko. Teknik penentuan sampel menggunakan purposive sampling dengan kriteria tekanan darah sistol adalah $\geq 140 \mathrm{mmHg}$ dan/atau tekanan darah diastol $\geq 90 \mathrm{mmHg}$, menderita hipertensi primer, penderita datang berobat ke Puskesmas dan menyetujui sebagai responden penelitian. Dari kriteria tersebut, sebanyak 30 orang responden mengikuti penelitian.

\section{Pengumpulan, Pengolahan dan Analisis Data}

Pada saat proses pengambilan data penderita hipertensi tidak mengkonsumsi obat antihipertensi. Pengambilan data diawali dengan memberikan waktu istirahat terlebih dahulu \pm 10 menit pada responden dan dilanjutkan dengan pengukuran tekanan darah. Tahap selanjutnya adalah memberikan intervensi kombinasi tehnik relaksasi nafas dalam dengan terapi akupresur selama 20 menit. Setelah itu tekanan darah responden diukur tiga kali yaitu: segera setelah intervensi, 15 menit setelah intervensi dan 30 menit setelah intervensi.

\section{Terapi akupresur}

Persiapan

1. Memberikan lingkungan yang nyaman dan tenang

2. Mengatur responden dengan posisi duduk tegak dan rileks

3. Menganjurkan responden memejamkan mata 
4. Menganjurkan responden menarik nafas melalui lubang hidung dalam-dalam

5. Menahan napas selama empat hitungan dan kemudian meghembuskan nafas perlahan-lahan melalui mulut dengan bibir sedikit terbuka

6. Menganjurkan responden mengulangi pola pernafasan sampai merasa rileks selama 20 menit

Pemberian akupresur

1. Melakukan pemijitan pada titik GB20 selama 4 menit

2. Melakukan pemijitan pada titik LI11 kanan dan kiri selama 4 menit

3. Melakukan pemijitan pada titik LI 4 kanan dan kiri selama 4 menit

4. Melakukan pemijitan pada titik PC6 kanan dan kiri selama 4 menit

5. Melakukan pemijitan pada titik LV3 kanan dan kiri selama 4 menit

Tahap akhir

1. Setelah selesai responden diminta membuka mata, tetap duduk dengan rileks selama 5 menit

2. Enumerator mengukuran tekanan darah. Alat untuk mengukur tekanan darah adalah sphygmomanometer digital. Prosedur pengukuran:

2. 1. Menekan tombol "START/STOP" untuk menghidupkan alat

2.2. Memastikan responden duduk dengan posisi kaki tidak menyilang tetapi kedua telapak kaki datar menyentuh lantai. Meletakkan lengan kanan responden di atas meja

2.3. Menyingsingkan lengan baju pada lengan bagian kanan responden dan memintanya untuk tetap duduk tanpa banyak gerak, dan tidak berbicara pada saat pengukuran

2. 4. Memasang manset pada lengan atas $\pm 2 \mathrm{~cm}$ di atas lipatan siku

2.5. Membiarkan lengan dalam posisi tidak tegang dengan telapak tangan terbuka ke atas. Memastikan tidak ada tekukan pada pipa manset

2.6. Mencatat hasil pengukuran tekanan darah (sistol, diastole \& MAP

2.7. Menekan tombol "START/STOP” untuk mematikan alat

\section{Analisis data}

Analisis diskriptif disajikan dalam bentuk frekuensi, rerata dan standar deviasi untuk mengetahui karakteristik subjek penelitian, sedangakan untuk mengetahui perbedaan tekanan darah sebelum dengan sesudah pemberian kombinasi tehnik relaksasi nafas dalam dengan terapi akupresur menggunakan uji Wilcoxon $(\alpha 0,05)$. 


\section{HASIL}

Tabel 1

Distribusi frekuensi berdasarkan jenis kelamin

\begin{tabular}{|c|c|c|}
\hline Karakteristik Responden & Jumlah $(\mathrm{N}=30)$ & Persentase (100\%) \\
\hline \multicolumn{3}{|l|}{ Jenis kelamin } \\
\hline Laki-laki & 5 & 16,7 \\
\hline Perempuan & 25 & 83,3 \\
\hline
\end{tabular}

DOI: https://doi.org/10.36990/hijp.v13i1.288.g543

Responden laki-laki sebanyak lima orang (16,7\%) dan perempuan 25 orang $(83,3 \%)$.

Tabel 2

Karakteristik Responden

\begin{tabular}{lll}
\hline \multicolumn{1}{c}{ Data } & \multicolumn{1}{c}{ Rata-rata } & Standar Deviasi \\
\hline Umur & 55,1 & $\pm 6,59$ \\
Lama hipertensi & 1,1 & $\pm 0,40$ \\
Tinggi badan & 159,03 & $\pm 5,98$ \\
Berat badan & 61,13 & $\pm 9,52$ \\
Indeks Massa Tubuh & 24,21 & $\pm 3,85$ \\
\hline
\end{tabular}

DOI: https://doi.org/10.36990/hijp.v13i1.288.g544

Rerata umur responden 55,10 tahun, lama hipertensi 1,10 tahun, tinggi badan 159,03 cm, berat badan 61,13 kg, dan Indeks Masa Tubuh (IMT) 24,21.

Tabel 3

Analisis komponen pengukuran tekanan darah dan uji statistik Wilcoxon

\begin{tabular}{lllll}
\hline $\begin{array}{c}\text { Komponen } \\
\text { Tekanan } \\
\text { Darah }\end{array}$ & Prates & \multicolumn{3}{c}{ Pascates } \\
\hline & & \multicolumn{1}{c}{$\mathbf{0}^{\prime}$} & \multicolumn{1}{c}{$\mathbf{1 5}$} & \multicolumn{1}{c}{$\mathbf{3 0}$} \\
\hline TD sistol & 152,33 & $142,67(\mathrm{P} 0,000)$ & $137,67(\mathrm{P} 0,000)$ & $136,00(\mathrm{P} 0,000)$ \\
TD diastol & 90,00 & $84,33(\mathrm{P} 0,000)$ & $83,00(\mathrm{P} 0,000)$ & $82,67(\mathrm{P} 0,000)$ \\
MAP & 110,78 & $103,78(\mathrm{P} 0,000)$ & $101,22(\mathrm{P} 0,000)$ & $100,44(\mathrm{P} 0,000)$ \\
\hline
\end{tabular}

DOI: https://doi.org/10.36990/hijp.v13i1.288.g545

Rerata nilai komponen TD sistol sebelum diberikan terapi sebesar 152,33 dan terus menurun setalah diberikanterapi akupresur, pada menit ke 0, 15, dan 30 . Nilai diastol, yang rerata nilainya sebelum diberikan akupresur sebesar 90,00 dan semakin menurun pada menit ke 0,15 , dan 30 sebesar 82,67 . Hal yang sama terjadi pada MAP nya. Hasil uji statistik menggunakan metode uji Wilcoxon signed rank $(\alpha 0,05)$ menghasilkan nilai P kurang kurang dari 0,05 . Hal ini terjadi pada ketiga komponen pengukuran tekanan darah. 


\section{PEMBAHASAN}

Hipertensi disebut juga dengan penyakit pembunuh diam-diam (silent killer), sehingga diperlukan deteksi dini dan penatalaksanaan hipertensi. Peningkatan tekanan darah pada hipertensi terjadi karena peningkatan curah jantung dan peningkatan tahanan perifer (Bolívar, 2013). Peningkatan curah jantung disebabkan karena keadaan yang menyebabkan frekuensi jantung meningkat, volume sekuncup meningkat atau keduanya. Sedangkan peningkatan tahanan perifer disebabkan oleh faktor-faktor yang meningkatkan vikositas darah atau yang menurunkan ukuran lumen pembuluh darah, khususnya pembuluh darah arteriol (McCance \& Huether, 2014).

Penatalaksanaan hipertensi dapat dilakukan secara farmakologis dan nonfarmakologis (Anderson et al., 2016). Penatalaksanaan non-farmakologis merupakan penatalaksanaan hipertensi tanpa menggunakan obat, yang dapat dilakukan secara mandiri oleh penderita hipertensi atau dengan bantuan orang lain atau tenaga kesehatan. Penelitian ini berusaha membuktikan upaya nonfarmakologis untuk menurunkan tekanan darah yaitu dengan memberikan kombinasi relaksasi nafas dalam dengan terapi akupresur.

Hasil penelitian ini menunjukkan bahwa pemberian kombinasi relaksasi nafas dalam dengan terapi akupresur dapat menurunkan tekanan darah pasien hipertensi (Tabel 3). Hal ini dibuktikan dengan terjadinya penurunan tekanan darah sistolik maupun diastolik, serta Mean Atrial Pressure (MAP) secara bertahap sampai dengan 15 menit kedua setelah kombinasi relaksasi nafas dalam dengan terapi akupresur. Prinsip dari tindakan ini adalah upaya untuk menurunkan tahanan perifer dan curah jantung pasien hipertensi sehingga tekanan darahnya turun.

Relaksasi nafas dalam merupakan salah tehnik relaksasi yang dapat berfungsi untuk menurunkan stress atau kecemasan (Elliya et al., 2021; Resti, 2014; Rokawie et al., 2017). Stress merupakan salah faktor yang dapat menyebabkan peningkatan tekanan darah (Anderson et al., 2016). Stress fisik maupun psikis dapat menstimulasi hipotalamus, secara langsung akan mengaktifkan sistem saraf simpatik, mensekresi Corticotropin Releasing Hormone (CRH) untuk merangsang pelepasan Adrenocorticotropic Hormone (ACTH) dan kortisol, dan memicu pelepasan vasopresin.

Stimulasi simpatik akan merangsang medula adrenal mensekresi epineprin yang menyebabkan vasokontriksi arteriol aferen ginjal sehingga aliran darah ke ginjal akan menurun. Hal tersebut akan memicu sekresi renin oleh ginjal yang mengaktifkan Renin Angiotensin Aldosteron System (RAAS) (Sherwood, 2010). Renin merupakan enzim yang disintesis, disimpan, dan dirilis oleh sel-sel juxtaglomerular ginjal sebagai respons terhadap peningkatan aktivitas sistim saraf pusat atau penurunan tekanan darah, volume cairan ekstraselular, atau konsentrasi natrium ekstraseluler (Grossman \& Porth, 2014). Renin dilepaskan oleh ginjal akan masuk dalam sirkulasi darah, yang peran sebagai enzim untuk merubah angiotensinogen menjadi angiotensin I, kemudian angiotesin I berubah menjadi angiotensin II oleh Angiotensin Converting Enzyme (ACE). Angiotensin II merupakan vasokonstriktor yang kuat terutama arteriol. Penyempitan arteriol meningkatkan tahanan perifer arteriol, sehingga berkontribusi pada peningkatan tekanan darah. Angiotensin 
II juga menstimulasi sekresi aldosteron oleh cortex adrenal menyebabkan terjadinya retensi natrium dan air di ginjal sehingga menyebabkan volume darah meningkat dan tekanan darah meningkat (Grossman \& Porth, 2014; McCance \& Huether, 2014; Sherwood, 2010).

Tehnik relaksasi nafas berperan dalam mengurangi aktivitas saraf simpatik dan meningkatkan aktivitas saraf parasimpatik (Komori, 2018). Peningkatan aktivitas saraf parasimpatik dapat menurunkan aktivitas kerja jantung melalui pelepasan neurotransmiter asetilkolin dan juga menurunkan sekresi hormon yang dipicu karena stress yang berefek pada penurunan tahanan perifer sehingga dapat menurunkan tekanan darah (Guyton \& Hall, 2015; McCance \& Huether, 2014). Teknik relaksasi nafas dalam merupakan salah tindakan nonfarmakologis dalam penatalaksanaan hipertensi untuk menurunkan tekanan darah (Cahyanti \& Febriyanto, 2019; Masnina \& Setyawan, 2018; Nurman, 2017; Parinduri, 2020). Hal ini sesuai juga dengan penelitian yang dilakukan Wijayanti (2017) terhadap 25 pasien hipertensi di RSUD dr. Loekmono Hadi Kudus didapatkan hasil ada pengaruh yang signifikan antara tekanan darah sebelum dan sesudah dilakukan teknik relaksasi nafas dalam (Wijayanti \& Setiyo, 2017).

Terapi akupresur merupakan upaya memberikan rangsangan (stimulasi) titik akupunktur dengan teknik penekanan atau teknik mekanik (Kemenkes RI, 2014). Pada penelitian ini penderita hipertensi dilakukan penekanan pada titik GB20, LI11, LI4, PC6 dan LV6. Manfaat terapi akrupresur adalah menurunkan stress, vasodilitasi pembuluh darah sehingga aliran darah lancar, dan menurunkan kinerja jantung sehingga frekuensi jantung turun (Ceyhan et al., 2019; McFadden \& Hernández, 2010; Tiwari et al., 2016). Berdasarkan manfaatnya, terapi akupresur dapat membantu menurunkan tekanan darah pada penderita hipertensi (Aminuddin et al., 2020; Santoso et al., 2011). Hal ini sesuai dengan penelitian yang dilakukan oleh Lin (2016) terhadap 80 pasien hipertensi yang terbagi menjadi kelompok perlakuan dan kelompok kontrol menunjukkan hasil terapi akupresur pada titik taichong dapat menurun tekanan darah pasien hipertensi (Lin et al., 2016).

\section{KESIMPULAN DAN SARAN}

Hasil penelitian ini dapat disimpulkan bahwa kombinasi relaksasi nafas dalam dengan terapi akupresur dapat menurunkan tekanan darah penderita hipertensi. Kombinasi relaksasi nafas dalam dengan terapi akupresur dapat digunakan sebagai penatalaksanaan non-farmakologis hipertensi untuk menurunkan tekanan darah.

Saran untuk peneliti selanjutnya yaitu supaya dapat menganalisis efektifitas kombinasi relaksasi nafas dalam dengan terapi akupresur dalam menurunkan tekanan darah pasien hipertensi, sehingga dapat diketahui durasi efeknya dalam menurunkan tekanan darah pada penderita hipertensi.

\section{Kekurangan Penelitian}

Keterbatasan dalam penelitian ini adalah kesulitan mengontrol subjek penelitian karena subjek dalam penelitian ini adalah manusia yang mempunyai karakteristik 
yang berbeda satu sama lainnya dan disamping itu banyak faktor yang dapat mempengaruhi tekanan darah seperti tingkat stress, aktivitas, umur, volume darah, vikositas darah dan lain-lainnya. Peneliti belum membahas faktor jenis kelamin, umur, IMT dan lamanya menderita hipertensi (Tabel 1; Tabel 2).

\section{Mengakui}

Penulis menyampaikan terimakasih kepada Direktur Poltekkes Kemenkes Ternate, Ketua Jurusan Keperawatan, Kepala Puskesmas Siko Kota Ternate, dan seluruh pihak yang telah terlibat dan membantu dalam pelaksanaan penelitian.

\section{DAFTAR PUSTAKA}

Aminuddin, A., Sudarman, Y., \& Syakib, M. (2020). Penurunan Tekanan Darah Penderita Hipertensi Setelah Diberikan Terapi Akupresur. Jurnal Kesehatan Manarang, 6(1), 57. https://doi.org/10.33490/jkm.v6i1.119

Anderson, C., Amolda, L., Cowley, D., \& Dowden, J. (2016). Guideline For The Diagnosis and Management of Hypertension In Adults. The Medical Journal of Australia, 205(2), 85-89. https://doi.org.10.5694/mja16.00526

Bolívar, J. J. (2013). Essential hypertension: an approach to its etiology and neurogenic pathophysiology. International Journal of Hypertension, 2013, 547809. https://d oi.org/10.1155/2013/547809

Cahyanti, L., \& Febriyanto. (2019). Pengaruh Teknik Relaksasi Nafas dalam Terhadap Penurunan Tekanan Darah pada Pasien Hipertensi di Rsud Dr. Soeratno Gemolong Tahun 2018. Prosiding HEFA, 6(1), 1-21.

Ceyhan, O., Taşc1, S., Elmalı, F., \& Doğan, A. (2019). The Effect of Acupressure on Cardiac Rhythm and Heart Rate Among Patients With Atrial Fibrillation: The Relationship Between Heart Rate and Fatigue. Alternative Therapies in Health and Medicine,25(1), 12-19. http://www.ncbi.nlm.nih.gov/pubmed/30982782

Elliya, R., Sari, Y., \& Chrisanto, E. Y. (2021). Keefektifan Relaksasi Nafas Dalam Terhadap Penurunan Stres Pada Lansia Di Uptd Pelayanan Sosial Lanjut Usia Tresna Werdha Natar Lampung Selatan. Malahayati Nursing Journal, 3(1), 5060. https://doi.org/10.33024/manuju.v3i1.1624

Grossman, S. C., \& Porth, C. M. (2014). Porth's pathophysiology: Concepts of altered health states (9th ed.). Wolters Kluwer Health.

Guyton, A. C., \& Hall, J. E. (2015). Textbook of Medical Physiology (13th ed.). Elsevier Saunders.

Kemenkes RI. (2013). Riset Kesehatan Dasar Tabun 2013. Kementrian Kesehatan Republik Indonesia

Kemenkes RI. (2014). Panduan Akupresur Mandiri Bagi Pekerja di Tempat Kerja. Kementerian Kesehatan Republik Indonesia.

Kemenkes RI. (2018). Riset Kesehatan Dasar Tahun 2018. Kementrian Kesehatan Republik Indonesia

Komori, T. (2018). The relaxation effect of prolonged expiratory breathing. Mental Illness, 10(1). https://doi.org/10.4081/mi.2018.7669

Lin, G. H., Chang, W. C., Chen, K. J., Tsai, C. C., Hu, S. Y., \& Chen, L. L. (2016). Effectiveness of Acupressure on the Taichong Acupoint in Lowering Blood Pressure in Patients with Hypertension: A Randomized Clinical Trial. Evidence- 
Based Complementary and Alternative Medicine, 2016. https://doi.org/10.1155/ 2016/1549658

Masnina, R., \& Setyawan, A. B. (2018). Terapi Relaksasi Nafas Mempengaruhi Penurunan Tekanan Darah Pada Pasien Lansia Dengan Hipertensi. Jurnal Imu Dan Teknologi Kesehatan, 5(2), 119-128.

McCance, K. L., \& Huether, S. E. (2014). Pathophysiology: the biologic basis for disease in adults and children (7th ed.). Elsevier.

McFadden, K. L., \& Hernández, T. D. (2010). Cardiovascular benefits of acupressure (Jin Shin) following stroke. Complementary Therapies in Medicine, 18(1), 42-48. https://doi.org/10.1016/j.ctim.2010.01.001

Nurman, M. (2017). Efektifitas Antara Terapi Relaksasi Otot Progresif dan Teknik Relaksasi Nafas Dalam Terhadap Penurunan Tekanan Darah pada Penderita Hipertensi Di Desa Pulau Birandang Wilayah Kerja Puskesmas Kampar Timur Tahun 2017. Jurnal Ners Universitas Pablawan Tuanku Tambusai, 1(2), 108126.

Parinduri, J. S. (2020). Pengaruh Tekhnik Relaksasi Nafas Dalam Terhadap Penurunan Tekanan Darah Pada Pasien Hipertensi Di Wilayah Kerja Puskesmas Sidangkal. Indonesian Trust Health Journal, 3(2), 374-380. https://doi.org/10.37104/ithj .v3i2.63

Rahayu, D. Y. S., Usman, R. D., Nirwana, N., \& Firnawati, F. (2018). Pengaruh Health Education mengenai Penyakit Hipertensi pada Lansia yang Tinggal di Panti Jompo. Health Information : Jurnal Penelitian, 10(2), 123-132. https:// doi.org/10.36990/hijp.v10i2.111

Resti, I. B. (2014). Teknik Relaksasi Otot Progresif Untuk Mengurangi Stres Pada Penderita Asma. Jurnal Ilmiah Psikologi Terapan, 02(01), 1-20. https://garuda. kemdikbud.go.id/documents/detail/1770254

Rokawie, A. O. N., Sulastri, S., \& Anita, A. (2017). Relaksasi Nafas Dalam Menurunkan Kecemasan Pasien Pre Operasi Bedah Abdomen. Jurnal Kesehatan, 8(2), 257. https://doi.org/10.26630/jk.v8i2.500

Santoso, E. B., Susilo, A. J., \& Pranata, A. E. (2011). Perbedaan Tingkat Tekanan Darah Sebelum Dan Sesudah Dilakukan Tindakan Akupresure Pada Penderita Hipertensi Lansia Di Palu Puger Kabupaten Jember. Jurnal Kesehatan Dr. Soebandi, 3(1), 154-160.

Saputra, R., Mulyadi, B., \& Mahathir, M. (2020). Penurunan Tekanan Darah Pada Lansia Penderita Hipertensi Melalui Terapi Spiritual Emotional Freedom Technique (SEFT) dan Akupresur Titik Taichong. Jurnal Ilmiah Universitas Batanghari Jambi, 20(3), 942. https://doi.org/10.33087/jiubj.v20i3.1068

Sherwood, L. (2010). Sherwood Human Physiology from cells to System (7th ed.). Cengage Learning.

Tiwari, A., Lao, L., Wang, A. X. M., Cheung, D. S. T., So, M. K. P., Yu, D. S. F., Lum, T. Y.S., Yuk Fung, H. Y. K., Yeung, J. W. F., \& Zhang, Z. J. (2016). Self-administered acupressure for symptom management among Chinese family caregivers with caregiver stress: A randomized, wait-list controlled trial. BMC Complementary and Alternative Medicine, 16(1). https://doi.org/10.1186/s12906-016-1409-1

WHO. (2013). Global Brief on Hypertension: Silent Killer, Global Public Health Crisis.

Wijayanti, S., \& Setiyo, W. E. (2017). Pengaruh Teknik Relaksasi Nafas Dalam Terhadap Penurunan Tekanan Darah Pada Pasien Hipertensi Di RSUD dr. Loekmono Hadi Kudus. Prosiding HEFA (Health Events for All), 1(1), 403-410. 


\title{
Catatan kaki
}

Catatan Penerbit Poltekkes Kemenkes Kendari menyatakan tetap netral sehubungan dengan klaim atas perspektif atau buah pikiran yang diterbitkan dan dari afiliasi institusional manapun.

Pernyataan Konflik Kepentingan Para penulis menyatakan tidak terdapat konflik kepentingan.

Kontribusi Penulis Imam Cahyo Murwidi (Conceptualization, Data curation, Formal Analysis, Funding Acquisition, Investigation,Methodology, Supervision, Validation, Writing-original draft, Writing-review \& editing); Rasdiyanah Muhlis (Conceptualization, Investigation, Methodology, Project administration, Resources, Validation).

Berbagi Data Tidak ada data yang dibagikan.

\section{Author notes}

\author{
imam.cahyo.murwidi@gmail.com
}

